\title{
A Correlational Study Between The Students' Motivation and Translation Ability in Reading Comprehension
}

\author{
Muhammad Andri Hamdani, Siswantoro, Teguh Sarosa \\ English Education Department \\ Teacher Training and Education Faculty \\ Sebelas Maret University of Surakarta
}

Email: andriham@ rocketmail.com

\begin{abstract}
This study aims at finding out whether there is a correlation between (1) the students' motivation and reading comprehension; (2) translation ability and reading comprehension; and (3) the students' motivation and translation ability in reading comprehension. The participants of the study were at the eleventh grade students of one state senior high school in Surakarta. The population of the study is all of the eleventh grade students while the sample is 36 students taken by using cluster random sampling technique. The method used in this study is descriptive research method, with category of correlational study. The instruments in collecting the data are questionnaire and test. The techniques which are used to analyze the data are Simple Correlation and Multiple Regression Correlation. The result of the data analysis shows that in the level of significance $\alpha=0.05$ (1) there is a positive correlation between the students' motivation and reading comprehension $\left(\mathrm{r}_{\mathrm{x} 1 \mathrm{y}}=0.576, \mathrm{t}_{\mathrm{o}}=4.105>\mathrm{t}_{\mathrm{t}}=1.7\right)$ and it is about $25.45 \%$; (2) there is a positive correlation between translation ability and reading comprehension $\left(\mathrm{r}_{\mathrm{x} 2 \mathrm{y}}=0.542, \mathrm{t}_{\mathrm{o}}=3.756>\mathrm{t}_{\mathrm{t}}=1.7\right)$ and it is about $19.86 \%$; and (3) there is positive correlation between the students' motivation, translation ability, and reading comprehension $\left(\mathrm{R}_{\mathrm{y} 12}=0.666\right.$ and $\left.\mathrm{F}_{\mathrm{o}}=13.125>\mathrm{F}_{\mathrm{t}}=2.33\right)$ and it is about $45.31 \%$.
\end{abstract}

Keywords: the students' motivation, translation ability, reading comprehension

\section{INTRODUCTION}

The goal of the language teaching is to develop communicative competence both in oral and written. In order to develop it, there are four basic language skills in English that are taught by teachers in classrooms. Those are listening, speaking, reading and writing (Brown, 2001:232). Dealing with those skills, Sadeghi (2013:243) believes that reading is the most important skill for second language learners in the academic context. It is quite clear why reading is important skill since the students who cannot read and comprehend a written language cannot be expected to be good in other content areas which will indispensably require reading ability (Decker, in Sadeghi 2013:243). Reading becomes an important skill that should be mastered considering the need of understanding international written information such as: books, articles, magazines, newspaper, and so on. To get information from the written sources, a good reading comprehension is required with the purpose to absorb the information from the text being read.

Reading comprehension plays an important role in teaching learning process. For students, it is important since those who have good reading comprehension can 
absorb information from unlimited references to gain knowledge which is useful to support their learning process. Dealing with reading, Aebersold \& Field (1995: 15) say that "reading is what happens when people look at the text and assign meaning to the written symbols in that text". It means that reading is an activity which involves the reader and the text whereby the reader interacts with the text to elicit the meaning of the written symbols in the text.

The main purpose of reading process is comprehension, whereby the readers are able to absorb the information from the text being read. Chastain (in Negari, 2011: 60) states that the purpose of reading:

Is to read for meaning or to recreate the writer's meaning. Reading to improve pronunciation, practice grammatical forms, and study vocabulary does not constitute reading at all because by definition, reading involves comprehension. When readers are not comprehending, they are not reading.

Successful comprehension allows the reader to acquire new information from the text and to reach academic success. Murcia (2001:187) says that "reading comprehension is reading to understand main ideas and relevant supporting information". Comprehension is important in reading. Without it, the reader only reads the text without getting the needed information from the text either explicitly or implicitly from the writer.

There are some factors which can influence reading comprehension; those factors can be internal and external of the readers. One of the factors that come from internal is motivation. Everyone has his own internal condition; it takes important role in his daily activity. One of the internal conditions is called motivation. Elliot
(2000:332) argues "motivation is an internal state that arouses us to action, pushes us in particular directions, and keeps us engaged in certain activities". It seems that motivation is very important in every activity including reading. By having motivation the students will have a power from inside that pushes them to act and action is the key of all success. Motivated students usually have strong desire to achieve the goal, consequently they will do the activity intensively and do their best in their attempt to achieve the planned outcome.

Further Pintrich et al. (in Elliot 2000:332) suggest that "motivation increases an individual's energy and activity level". It means that motivation determines the extent to which a student is likely to engage in certain activity intensively and enthusiastically or half-heartedly. Stipek (in Elliot, 2000:332) asserts "motivation promotes initiation of certain activities and persistence in those activities". Thus in reading activity, motivation can be viewed as a stimulus that drives students to be more focused on the text in order to get better understanding of the text being read. It drives the students to struggle, give extra effort and maintain persistence in their attempt to reach the goal in reading process that is to get maximum comprehension. By having strong motivation they will not easily get frustrated when they encounter difficulties that appear during the process of comprehension, in contrast to those who do not have motivation who tend to give up easily. For example in reading activity, if they find difficulty in the meaning of the words, motivation will drive them to seek for a help by opening the dictionary and looking up the words that they do not know.

Another factor that is considered to influence reading comprehension is 
translation ability. For EFL learners, translation is an important skill that interrelates with the other four basic language skills. Ross (in Maasoum \& Mahdiyan, 2012:263) says that:

Translation holds a special importance at an intermediate and advanced level: in the advanced or final stage of language teaching, translation from the first language (L1) to second language (L2) and L2 to L1 is recognized as the fifth skill and the most important social skill since it promotes communication and understanding between strangers.

Further Liao (in Maasoum \& Mahdiyan, 2012:263) adds that "translation is found to be a frequently used learning strategy". Translation is a prevalent strategy that is used by many EFL students in learning English. Translation has a good position in language learning since it helps students to build better connection between their mother tongue and the target language.

Dealing with reading comprehension, translation is often used by the EFL learners as a strategy to comprehend the L2 text. EFL learners are likely relying on their mother tongue to attempt to gain understanding from the text they read. Maasoum \& Mahdiyan (2012: 264) believe that when EFL learners read a text, either consciously or unconsciously they tend to translate it in order to make it meaningful to themselves. Further Upton (1997: 1) states that "reading in second language (L2) is not monolingual event and L2 readers have access to their first language (L1) as they read and many use it as strategy to help comprehend an L2 text". Thus dealing with reading comprehension, translation can be viewed as a strategy for EFL students to construct the meaning in another language that allows them to relate their knowledge of the subject matter in their mother tongue to make easy the process of comprehending the L2 text. So when EFL learners try to comprehend the L2 text by using their mother tongue, their translation ability or their ability to transfer meaning from second language into their mother tongue will be very beneficial for them. By having good translation ability they will be easier in understanding the author's message on the text.

Further, for EFL students, translation is considered as an effective way in learning new vocabulary which is useful to improve their reading comprehension. Through translation with new words are linked to their mother tongue equivalents, it eases them to memorize new words meaning and probably they will keep it longer in their mind. This notion is supported by Husain on his research (in Liao, 2006:196), who concluded that "translation strategy could enhance English learning in general. It also discovers that students who use translation tend to make more gains in learning vocabulary and phrases". It is also strengthened by Liao (2006: 201) who says "translation eases memory constraints in memorizing more words, idioms, grammar, and sentence structures".

Reading is one of the most important skills in learning language. Through reading we can extract a lot of information from unlimited written sources to gain knowledge which is useful in academic and daily lives. The fundamental purpose of reading process is comprehension. The result of successful comprehension allows the reader to acquire new information from the text which is useful to broaden the knowledge. Murcia (2001:187) says reading comprehension is reading to understand main ideas and relevant supporting information. In line her, Grellet (1981:3) adds that "reading comprehension is understanding a written 
text means extracting the required information from it as efficiently as possible". These ideas above are also supported by Kustaryo (1988:11), who emphasizes that reading with comprehension means understanding what has been read. It is an active, thinking process that depends not only on comprehension skill but also on the reader's experience and background knowledge. In other words, it can be said that in order to understand the text the reader must have background knowledge so their attempt to understand the text become easier.

Thus, from the definition above it can be concluded that reading comprehension is the thinking process of understanding the ideas and extracting the required information of the text which involves the reader's background knowledge through interaction and involvement with written language.

Motivation is one of the important things that determine the success in every activity. According to Elliot et al., (2000:332) motivation is "an internal state that arouses us to action, pushes us in particular directions, and keeps us engaged in certain activities". In line with Elliot et al., Dornyei (1998:118) suggests that motivation is "the process whereby a certain amount of instigation force arise, initiates action, and persist as long as no other forces comes into play to weaken it and thereby terminate action, or until the planned outcome has been reached". In addition, Crowl et al., (1997:231) believe that persistence and focused behavior are the most prominent characteristics of motivation. Motivated people are likely will be engaged in goal-directed behavior and persist until they have achieved the goal.

From the definitions above, it can be concluded that motivation refers to an internal state whereby a certain amount of instigation force arises that energizes someone to do something and maintains persistence and focuses on doing the activity until the planned outcome is achieved.

For EFL learners, translation is important skill that cannot be neglected together with four major skills. According to Newmark (1988: 7) "translation is a craft consisting in the attempt to replace a written language message and/or statement in one language by the same message and/or statement in another language". Another definition is proposed by Brislin (in Suryawinata, 2003: 12) who asserts that "translation is a general term referring to the transfer of thoughts and ideas from one language (source) to another (target) whether the language are in written and oral". Further Nida \& Taber (1974: 12) state that "translation consists in reproducing in the receptor language the closest natural equivalent of the source language message, first in terms of meaning and secondly in terms of style". In this case, the most important is that the translator should transfer the meaning or content of the message into the TL as appropriately as possible, whereas the style or the form may change into another form.

From the definitions above, it can be concluded that translation is a process of transferring a written or oral thoughts, ideas, information, and messages from one language (Source Language) into another language (Target Language) by considering the equivalence of meaning. But in this research, the researcher only restricts translation only in transferring the written messages. In this case, the messages are from English into Indonesian. 


\section{RESEARCH METHODS}

The method used in this research is correlational method. According to Halonen \& Santock (1999: 20), correlational method is a method of which goal is to describe the relation between two or more events or characteristics. The writer uses this method because he wants to know the relationship between the three variables based on correlation coefficient.

There are three variables of this research. The three variables can be divided into two independent and one dependent variables. The independent variables are students' motivation $\left(\mathrm{X}_{1}\right)$ and translation ability $\left(\mathrm{X}_{2}\right)$, while the dependent variable is reading comprehension $(\mathrm{Y})$.

This research is carried out at the eleventh grade students at one of state senior high school in Surakarta. The sample is class

XI-IPA 3 which consists of 36 students taken by cluster random sampling technique.

The data are collected by using test and questionnaire. The tests are used to collect reading comprehension data (in the form of multiple choice test which consists of 41 items) and translation ability data (which consists of 40 items) while the questionnaire is used to collect the data of the students' motivation (which consists of 46 items having four alternatives positive and negative items). Before the instruments are used to collect the data, all items of each instrument above have been tried out to make sure that the instruments are valid and reliable. The validity test is analyzed by using Product Moment Formula and the reliability test is analyzed by using KuderRichardson 20 Formula for multiple choice instrument (the discrete score) and Alpha Cronbach Formula for questionnaire instrument (continuum score).

Before analyzing the data, there are pre-requisite test that should be done. It covers normality test, linearity of regression test, significance of regression test, and homogeneity test. After pre-requisite test is finished, the next step is analyzing the data to test the hypotheses. The researcher uses Product Moment Formula and Multiple Linear Regression Formula to test the hypotheses. Product Moment Formula is used to find out the correlation between two variables $\left(\mathrm{X}_{1}-\mathrm{Y} / \mathrm{X}_{2}-\mathrm{Y}\right)$ and Multiple Linear Regression Formula is used to figure out the correlation between two independents variables simultaneously and one dependent $\operatorname{variable}\left(\mathrm{X}_{1}, \mathrm{X}_{2}-\mathrm{Y}\right)$.

\section{RESEARCH FINDINGS AND DISCUSSIONS}

The result of the normality test of the students' motivation, translation ability, and reading comprehension data can be described in table 1.

Table 1. Normality Test of the Students' Motivation, Translation Ability, and Reading Comprehension

\begin{tabular}{lccc}
\hline & $\mathbf{X}_{\mathbf{1}}$ & $\mathbf{X}_{\mathbf{2}}$ & $\mathbf{Y}$ \\
\hline$N$ & 36 & 36 & 36 \\
Mean & 138 & 33.72 & 36.66 \\
Standard Deviation & 9.661 & 3.234 & 2.501 \\
& 0.0390 & 0.0134 & -0.0067 \\
$L_{t}$ & 0.1476 & 0.1476 & 0.1476 \\
Status & Normal & Normal & Normal \\
\hline
\end{tabular}

Note:

$X_{I}$ : the students' motivation; $X_{2}$ : translation ability; $Y$ : reading comprehension; $L_{o}$ : L-obtained; $L_{t}:$ L-table 
From the table 1, it can be concluded that the data of the students' motivation $\left(\mathrm{X}_{1}\right)$, translation ability $\left(\mathrm{X}_{2}\right)$, and reading comprehension (Y) are in normal distribution.
Meanwhile, the result of the linearity of regression test of: (1) the students' motivation and reading comprehension and (2) translation ability and reading comprehension can be described in table 2 .

Table 2. Linearity of Regression Test of the Students' Motivation, Translation Ability, and Reading Comprehension

\begin{tabular}{ccccc}
\hline Variants & $\begin{array}{c}\text { Degree of Freedom } \\
\text { (d.f.) }\end{array}$ & Value of & Value of & Status \\
\hline $\mathrm{X}_{1}$ and $\mathrm{Y}$ & $18: 16$ & 0.548 & 2.28 & Linear \\
$\mathrm{X}_{2}$ and $\mathrm{Y}$ & $11: 23$ & 0.829 & 2.27 & Linear \\
\hline
\end{tabular}

Note:

$X_{1}$ : the students' motivation; $X_{2}$ : translation ability; $Y$ : reading comprehension ; $F_{o}$ : F-obtained;

$F_{t}$ : F-table

From the table 2, it can be concluded that the regression of: (1) the students' motivation and reading comprehension and (2) translation ability and reading comprehension is linear.
Furthermore, the result of the significance of regression test of: (1) the students' motivation and reading comprehension and (2) translation ability and reading comprehension can be described in table 3.

Table 3. Significance of Regression Test of the Students' Motivation, Translation Ability, and Reading Comprehension

\begin{tabular}{ccccc}
\hline Variants & $\begin{array}{c}\text { Degree of Freedom } \\
(\text { d.f. })\end{array}$ & Value of & Value of & Status \\
\hline $\mathrm{X}_{1}$ and $\mathrm{Y}$ & $1: 34$ & 16.847 & 4.17 & Significant \\
$\mathrm{X}_{2}$ and $\mathrm{Y}$ & $1: 34$ & 14.103 & 4.17 & Significant \\
\hline
\end{tabular}

Note:

$X_{I}$ : the students' motivation; $X_{2}$ : translation ability; $Y \quad$ : reading comprehension; $F_{o}$ :

F-obtained; $F_{t:}:$ F-table

From the table 3 , it can be concluded that the regression of: (1) the students' motivation and reading comprehension and (2) translation ability and reading comprehension is significant.
Further, the result of the homogeneity test of: (1) the students' motivation and reading comprehension and (2) translation ability and reading comprehension can be described in table 4 
Table 4. Homogeneity Test of the Students' Motivation, Translation Ability, and Reading Comprehension

\begin{tabular}{cccc}
\hline Variants & $\begin{array}{c}\text { Value of } \\
\boldsymbol{X}^{\mathbf{2}}\end{array}$ & Chi Square Table & Status \\
\hline $\mathrm{X}_{1}$ and $\mathrm{Y}$ & 15.714 & 26.296 & Homogeneous \\
$\mathrm{X}_{2}$ and $\mathrm{Y}$ & 11.926 & 35.132 & Homogeneous \\
\hline
\end{tabular}

Note:

$X_{1}$ : the students' motivation; $X_{2}$ : translation ability; $Y$ : reading comprehension ; $X^{2}$ : the value of chisquare

From the table 4, it can be concluded that the data of the students' motivation $\left(\mathrm{X}_{1}\right)$, translation ability $\left(\mathrm{X}_{2}\right)$, and reading comprehension (Y) are homogeneous.

From the analysis of the hypotheses testing, the first hypothesis testing finds that from the computation of simple regression analysis of $\mathrm{X}_{1}$ and $\mathrm{Y}$, it shows that the value of coefficient $a=15.33$, and $b=0.15$. Therefore, the regression equation $(\hat{\mathrm{Y}}=\mathrm{a}+$ $\mathrm{bX}_{1}$ ) becomes …................................ This can be used to predict the correlation between the students' motivation $\left(\mathrm{X}_{1}\right)$ and reading comprehension $(\mathrm{Y})$. It means that the mean of reading comprehension (Y) would increase 0.15 if the students' motivation $\left(\mathrm{X}_{1}\right)$ is increased in one score in the constant score of 15.33.

From the computation of single correlation by using Product Moment Formula, it is known that the first hypothesis saying that there is a positive correlation between the students' motivation and reading comprehension is accepted. The result of the first hypothesis testing computation shows that the correlation coefficient $\left(\mathrm{r}_{\mathrm{x} 1 \mathrm{y}}\right)$ between the students' motivation $\left(\mathrm{X}_{1}\right)$ and reading comprehension $(\mathrm{Y})$ is 0.576 and after being calculated to the $t$-value, $t_{o}(4.105)$ is higher than $t_{t}(1.70)$ or $\left(t_{0}>t_{t}\right)$. It means that there is a significant, positive correlation between the students' motivation and reading comprehension of students in the academic year of 2013/2014.
From the computation of the effective contribution, it is shown that the effective contribution of the students' motivation $\left(\mathrm{X}_{1}\right)$ to reading comprehension (Y) is $25.45 \%$. It means that $25.45 \%$ of reading comprehension is determined by the students' motivation and the rest $74.55 \%$, is determined by other factors.

It appears that motivation is one of the internal factors that determines the success in doing any activity including in reading comprehension. In reading context, motivated students are likely will be more concentrated on the text and thus they comprehend better. Motivation also increases that they will try to understand material, to learn it meaningfully rather than learning in superficial. And probably motivation will help them to keep the information from the text longer in their mind. This notion is supported by Brown (in Slavin, 1997:346), who says that "students who are motivated to learn something use higher cognitive process in learning about it and absorb and retain more from it". It is also strenghtened by Guthrie et al. (2005: 403) who say that "motivavtion and engagement influence development of reading comprehension because motivated students usually want to understand fully and, therefore process information deeply".

Based on the brief analysis above, it can be concluded that there is a positive correlation between the students' motivation 
and reading comprehension. It also means that the increase of the students' motivation will be followed by the increase of reading comprehension.

The second hypothesis reveals that from the computation of simple regression analysis of $X_{2}$ and $Y$, it shows that the value of coefficient $a=22.72$ and $b=0.42$. Therefore, the regression equation $(\hat{\mathrm{Y}}=\mathrm{a}+$ $\mathrm{bX}_{2}$ ) becomes . This can be used to predict the correlation between translation ability $\left(\mathrm{X}_{2}\right)$ and reading comprehension (Y). It means that the mean of reading comprehension (Y) would increase 0.42 if translation ability $\left(\mathrm{X}_{2}\right)$ is increased in one score in the constant score of 22.72 .

From the computation of single correlation by using Product Moment Formula, it is known that the second hypothesis saying that there is a positive correlation between translation ability and reading comprehension is accepted. The result of the computation shows that the correlation coefficient $\left(\mathrm{r}_{\mathrm{x} 2 \mathrm{y}}\right)$ between translation ability and reading comprehension is 0.542 and after being calculated on the $t$-value, $t_{o}$ (3.756) is higher than $t_{t}(1.70)$ or $\left(t_{o}>t_{t}\right)$. It means that there is a significant, positive correlation between translation ability and reading comprehension of the students.

From the computation of the effective contribution, it is shown that the effective contribution of the translation ability $\left(\mathrm{X}_{2}\right)$ to reading comprehension ( $\mathrm{Y}$ ) is $19.86 \%$. It means that $19.86 \%$ of reading comprehension is determined by the students' motivation and the rest $80.14 \%$, is determined by other factors.

Machida (2011: 740) believes that "when people try to understand ideas or meaning in a new SL/FL language, L1 will naturally play a major role in your comprehension". As explained before that when EFL learners read the L2 text, they tend to translate it into their mother tongue. So when they try to understand the L2 text by using their first language, their translation ability is apparently will be very helpful for them for the purpose of checking their comprehension in regard with avoiding misunderstanding the expressions and ideas on the L2 text. In this case, their translation ability is reflected by their ability to transfer meaning accurately or to find the equivalent replacement meaning from the source language (English) into the target language (Indonesian). Further Negari (2011: 61) asserts that "learners can develop their reading comprehension ability by translating target language text into their native language".

Based on the brief explanation above, it can be concluded that there is a positive correlation between translation ability and reading comprehension. It also means that the increase of translation ability will be followed by the increase of reading comprehension.

The third hypothesis reveals that from the computation of multiple linear regression test, the value of coefficient of

$=12.19,=0.11$, and $=0.29$. Therefore, the multiple linear regression equation of $\mathrm{Y}$ on $\mathrm{X}_{1}$ and $\mathrm{X}_{2}$ becomes

The multiple linear regression test also shows that the value of is 13.125. Then, the value of

(13.125) is consulted to $F$-table at the significance level $\alpha=0.05$ and the degree of freedom (d.f.) for 2:33 (3.32). Because

$(13.12)>(3.32)$, it can be concluded that the multiple linear regression is significant. Therefore, it can be used to predict the correlation between the students' motivation $\left(\mathrm{X}_{1}\right)$ and translation ability $\left(\mathrm{X}_{2}\right)$ simultaneously and reading comprehension 
(Y). It means that in every one score increase from the students' motivation $\left(\mathrm{X}_{1}\right)$ together translation ability $\left(\mathrm{X}_{2}\right)$, there will be an increase of 0.40 of the reading comprehension $(\mathrm{Y})$ in the constant score of 12.19 .

Meanwhile, from the multiple correlation computation using Regression Line Analysis, it is shown that the value of the coefficient of multiple correlations $(R)$ is 0.666 and $R^{2}$ is 0.443 . The significance testing of this coefficient in $F$ observation is 13.125. After being calculated on the Fvalue, the value of $F_{o}(13.125)>F_{t}$ (3.32). It can be concluded that the coefficient of multiple correlation $(\mathrm{R})$ is significant.

From the computation of the effective contribution, it is also found that the effective contribution of the students' motivation and translation ability toward reading comprehension is $45.31 \%$. It means that $45.31 \%$ variance of reading comprehension (Y) is influenced by the students' motivation and translation ability and $54.69 \%$ is influenced by other factors. Then, it also means that the increase of the students' motivation and translation ability will be followed by the increase of their reading comprehension.

Dornyei (1998:117) says that "motivation has been widely accepted by both teachers and researchers as one of the key factors that influences the rate and success of second/foreign language (L2) learning". It seems that such claim is not erroneous, it is not arguable that motivation is one of the key factors that determines the success of learning in general and may reading in particular. It can be said that by having strong motivation, the students will be more enthusiastic in teaching learning process so they will be more encouraged to study well in order to reach the goal of teaching learning process. Simultaneously, through translation, the students tend to be more focused on the text since translation covers all textual elements. Translation requires very careful attention to both form and meaning in the source language in order to transfer the meaning into other forms in another language. As they focus on the text being read, it increases the likelihood that they will get maximum comprehension. When translating a text, the students come into cantact with all the main ideas and specific details of reading passages as Bassnett (in Sadeghi, 2013: 247) believes "translation offers a crucial lesson in how to read, since it is a critical way into the text. It is as an effective means of forcing the students to read texts thoughtfully and to concentrate on the lexical, grammatical and textual levels, and improving general knowledge, while unveiling students' problems in comprehending (English) texts".

From the explanation above, it is quite clear that the students' motivation and translation ability simultaneously build a good relationship and give contribution toward reading comprehension.

\section{CONCLUSIONS AND SUGGESTIONS}

From the result of the study, the researcher describes some conclusions. First, there is significant, positive correlation between the students' motivation and reading comprehension of the students. The effective contribution of the students' motivation to reading comprehension is $25.45 \%$. It means that the increase of students' motivation will be followed by the increase of the students' reading comprehension.

Second, there is significant, positive correlation between translation ability and reading comprehension. The effective contribution of translation ability to reading 
comprehension is $19.86 \%$. It means that the increase of students' translation ability will be followed by the increase of students' reading comprehension.

Third, there is significant, positive correlation between the students' motivation and translation ability simultaneously and reading comprehension. The total effective contribution of the students' motivation and translation ability to reading comprehension is $45.31 \%$. It means that the increase of students' reading habit and translation ability simultaneously will be followed by the increase of the students' reading comprehension.

Considering that motivation and translation ability give contribution to reading comprehension, it is important for the teachers to increase the students' motivation and their translation ability. The teachers are expected to enhance the students' motivation since it is one of the main factors that determine the success of learning in general and reading comprehension in particular. In the classroom context, there are some ways that can be used by the teachers to promote the students' motivation, such as creating a pleasant atmosphere in the classroom, relating classroom materials to students' interest, rewarding students for good performance, and developing a good relationship with the students.

Teachers should help the students to improve their translation ability in order to help them get success in reading comprehension. The teachers should improve their professional skill, especially in translation ability. The students also should study well and do many exercises in translating text to achieve good translation. For other researchers, it is suggested to conduct another research in the same field as the writer has done. The purpose is to find other predictor variables, which are supposed to support reading comprehension. The last, hopefully this research will be very useful as a reference for the other researchers who carry out and develop a similar study.

\section{BIBLIOGRAPHY}

Aebersold, Jo ann. Field, Mary Lee. 1997. From Reader to Reading Teacher: Issues and Strategies for Second Language Classroom. Cambridge: Cambridge University Press.

Brown, H. Douglas. 2001. Teaching by Principles. New York. Addison Wesley Longman, Inc.

Crowl, et al. 1997. Educational Psychology: Windows on Teaching. The College of State Island: Brown \& Benchmark.

Dornyei, Zoltan. 1998. "Motivation in Second and Foreign Language Learning". Journal of Language Teaching, 31, pp 117-135.

Elliot et al. 2000. Educational Psychology. Mc Graw Hill: The Mc Graw Hill Companies.

Grellet, Franchoise. 1981. Developing Reading Skill. Cambridge: Cambridge University Press.

Guthrie et al. 2004. "Increasing Reading Comprehension and Engagement Through Concept-Oriented Reading Instruction". Journal of Educational Psychology, Vol 96, No 3, 403-423.

Hallonen, Jane S and Santock, John W. 1999. Psychology: Applied and Application $3^{\text {rd }}$. USA: Mc Graw-Hill College. 
Kustaryo, Sukiryah. 1988. Reading Techniques for College Student. Jakarta: Depdikbud.

Liao, Posen. 2006. "EFL learners' Beliefs about and strategy Use of Translation in English Learning". Regional Language Centre Journal Vol 37(2) 191-215.

Maasoum, Sayyed Mohammad Hosaini. Mahdiyan, Mehdi. 2012. “Applying Translatioon in EFL Reading Courses of Iranian Adult Learners". Journal of Educational and Social Research Vol. 2(2).

Machida, Sayuki. 2011. "Translation in Teaching a Foreign (Second) Language: A Methodological Theory". Journal of Language Teaching and Research. Vol.2, No. 4,740-746.

Murcia, Marianne Celce. 2001. Teaching English as a Second or Foreign Language. Boston: Heinle \& Heinle.

Negari, Giti Mousapour. 2011. "The Role of Translation in the Improvement of EFL Learners' Reading Comprehension at the Intermediate Level of Language Proficiency". Journal of Higher Education Theory and Practice vol. 11(3).

Newmark, Peter. 1988. Approaches to Translation. London: Oxford Penguin Press.

Nida, E.A and Taber, C.R. 1974. The Theory and Practice of Translation. Netherland: E.J Brill.

Sadeghi, Bahador et al. 2013. "The Effect of Translation Activities on Reading Comprehension of Iranian EFL Students". International Journal of
Language and Applied Linguistic World. Vol 3(4), 243-253.

Slavin, Robert E. 1997. Educational Psychology: Theory and Practice. USA: A Viacom Company.

Suryawinata, Zuchridin and Hariyanto, Sugeng. 2003. Translation: Bahasan Teori dan Penunutun Praktis Menerjemahkan. Yogyakarta: Kanisius.

Upton, Thomas A. 1997. "First and Second Language Use in Reading Comprehension Strategies of Japanese ESL Students". The Electronic journal for English as a Second Language. Vol.3.No.1. 